UDC $37.014 .5 / 25$

DOI: https://doi.org/10.30839/2072-7941.2018.155557

\title{
THE ELITE QUALITY OF HIGHER EDUCATION AS A CONSEQUENCE OF GLOBAL INTERNATIONALIZATION
}

\author{
(C) DEBYCH, M. A. \\ Institute of Higher Education, National Academy of Educational Sciences \\ (Kyiv, Ukraine) \\ E-mail: m_debych@ukr.net, ORCID: 0000-0002-5999-3989 \\ (C) HUMENNA, O. A. \\ Institute of Higher Education, National Academy of Educational Sciences \\ (Kyiv, Ukraine) \\ E-mail: enrietta@ukr.net, ORCID: 0000-0003-3644-8758
}

\begin{abstract}
The relevance of the research topic. After the World War II the leaders and intellectuals of the world were forced to look for new principles and methods of management. New theories for analysis of complex systems appeared. The D. Meadows' group from the Club of Rome and other analysts discovered the fact of the deepening humanity in an irreversible and deadly crisis. Up to now, economists and politicians have not offered a way to guarantee rescue. However, there is a consensus that hopes can be linked to the development of education and science in the world. The phrase "internationalization of higher education (IHE)" is used more and more often, and the number of scientific works is growing rapidly. However, in our opinion, the phenomenon of IHE is perceived superficially because of inattention to the latest scientific achievements, which are not followed by humanities scholars. This caused our interest and stimulated the desire to prove that global process of IHE started in accordance with the laws of the evolution of industrial production.

The purpose of our study is to apply the theory of analysis of very large systems to the phenomena of kinds and variants internationalization to obtain the most probable scenarios for human progress. The task of the study is seen in the critical analysis of the trend we noted in the process of training the $\mathrm{PhD}$-level professional in space and time and transforming the figure of a young worker from a national to an international "product" of the systems of education and training. The methodology of the research was dictated by the chosen goal and tasks under the pressure of the grandiose object - a complex of educational systems in a globalized planet environment. This is due to the use of the means of many sciences, theories of systemic research and a multidisciplinary approach in the conditions of global evolutionism.

The results of the study in their essence, are still based on historical methods, in conjunction with the achievements of young sciences - synergetics, theories of complex systems, and others. An original table was created to match the agrarian, industrial and informational societies - those within which the system of higher education had been developed. The direction of its characterization has proven that the autonomy of universities has been diminished at present, the size of the whole system and its orientation towards political and economic demands have increased. It is indicated at the time when the high school began to lose its national character and to acquire features of internationality. It is noted that this coincided with the growth of the volume and impact of globalization and its study mainly within the humanities.
\end{abstract}

The elite quality of higher education as a consequence of global internationalization 
The widespread representation of the interaction in higher education with the influences of globalization and internationalization, the basic definitions and differentiation, etc. is presented. The newest data on internationalization within the universities and far beyond them in state and interstate institutions are presented.

The conclusions and recommendations formulated and proved the main hypothesis of our study and its main result. It consists in the fact that the higher school in general began to reproduce the path of industry with its variant of internationalization - a combination of products of many countries. We argue that in higher education the division of time and space of educational programs, institutions, places of internship, etc. began. Instead of ensuring $\mathrm{PhD}$ competences within a single state, basic schooling is found to be more profitable in one place, the profile secondary is in the other, the baccalaureate or master's program in the country "A", postgraduate study somewhere in "B", the final professional development in the best world's centers of MBA or some other training in London or Harvard. From this follows the following conclusion: Ukraine's resources are already inadequate for the preparation of national personnel of the highest world quality. Such a "product" has already become international.

Key words: the evolution of higher education, the crisis of mankind, the role of science and higher education, globalization and internationalization, the quality of higher education, $\mathrm{PhD}$ specialists as an international product.

\section{The relevance of the research} topic. Currently humanity has reached the maximum in its number and variety of achievements and peaks. This could only be welcomed if not exacerbated by the immigration, terrorist, demographic and environmental threats for its existence. Scientists do not suggest a real way out of this crisis, they are satisfied with the calls, as it is done in "Scientists' Warning: Second Notice" at the end of 2017 by 15434 qualified biologists [13].

Among the proposals we see only an increase of reserves and debris recycling, which is too small for the general salvation. If the media are obscured on the themes of terrorism and global warming, then the scientific world as a whole is most concerned with the analysis of the various consequences of globalization in terms of strengthening economic cooperation and interdependence, the advent of the "fourth technological revolution" and the prospects of ripening "smart society" (the number of new concepts involving the word smart grows amazingly fast that we can not congratulate).

Two traditional phrases "higher education" and "quality of education" also indicate an increase in its relevance. It was transformed into a banal recognition that the educational and scientific complex has become not only the basis for the progress of states and the development of their human potential, but also a prerequisite for great success in the increasingly active and consolidated world market of goods and services. In order to describe the phenomena in this area, the phrase "internationalization of higher education" is increasingly being used, the number of scientific works is growing rapidly along with attention to it in the analytical materials and documents of all the major 
international organizations - UNO, OECD, EU, WB, UNESCO and etc.

However, in all these materials, in our opinion, the phenomenon of internationalization of higher education is perceived superficially, shallowly and without consideration of the inevitable deepening of the global phenomena that we discovered during our study. Therefore, in this article we give evidence that the process of total globalization of higher education in the world is already underway in accordance with the laws of the evolution of industrial production, but not of education.

The purpose of our study is to apply a theory of systemic research to the phenomena of kinds and variants internationalization with the obtaining of the most probable scenarios for human progress.

The task of the study is seen in the critical analysis of the trend we noted for the process of training the highest qualifications in space and time and transforming the figure of a young worker from a national to an international "product" of the existing classical and new systems of education and training.

The methodology of the research is being dictated by the chosen goal and tasks under the pressure of the grandiose volume and complexity of the research object - the complex of educational systems in the globalized planet environment. By means of classical sciences such as philosophy, pedagogy, psychology, sociology, or history we will add the systematic research inventors' recommendations, the achievements of synergetics with the assertion about the inevitability of the coming intersection the point of bifurcation in the world's evolution. We will conduct interdisciplinary analyses, trying to rely on the latest discoveries of the sciences and the humanities.

Results of the research. We will start their presentation with the forced, but the shortest, historical excursion, because we need a combination of ideas about the social evolution of humanity and its present state. We use for this not attractive work of the researchers of the information and technological revolution (M. Castells, R. Kurzweil, F. Fukuyama), but the proposals of practically the classics of Western sociology and futurology - D. Bell and E. Toffler. The first feared to clarify the name of the society of the future, rightly calling it "postindustrial", and the second proposed to reproduce the main stages of evolution through the model of three civilizational waves - agrarian, industrial and informational $([2 ; 3 ; 5]$, etc.). Let's recreate some of the characteristics of the respective societies in the form of a table and we will emphasize the emergence and development of higher education, in particular - universities, but not productions. 
Evolution of production and higher education on the basis of the Toffler's model of "three waves"

\begin{tabular}{|c|c|c|c|}
\hline \multirow{2}{*}{ CHARACTERISTICS } & \multicolumn{3}{|c|}{ SOCIETIES } \\
\hline & Agrarian & Industrial & Informative \\
\hline 1. Period of domination & $\begin{array}{l}\text { till the XVIIth } \\
\text { century. }\end{array}$ & XVII - XX & since 1980 and onwards \\
\hline $\begin{array}{l}\text { 2. Earth's population } \\
\text { (people) }\end{array}$ & tens of millions & $\begin{array}{l}\text { from hundreds of } \\
\text { millions to } 5 \\
\text { billion }\end{array}$ & $6-10$ billion \\
\hline $\begin{array}{l}\text { 3. Technology and } \\
\text { machinery }\end{array}$ & mechanical & $\begin{array}{l}\text { industrial } \\
\text { machine }\end{array}$ & industrial and digital \\
\hline $\begin{array}{l}\text { 4. Production (dominant } \\
\text { type) }\end{array}$ & $\begin{array}{l}\text { manual and for } \\
\text { immediate } \\
\text { consumption }\end{array}$ & $\begin{array}{l}\text { mass and } \\
\text { standardized }\end{array}$ & $\begin{array}{l}\text { mass and increasingly } \\
\text { individualized }\end{array}$ \\
\hline 5. Dominant product & $\begin{array}{l}\text { food, handicrafts, } \\
\text { weapons }\end{array}$ & $\begin{array}{l}\text { industrial } \\
\text { products, } \\
\text { weapons }\end{array}$ & $\begin{array}{l}\text { products, knowledge, } \\
\text { information }\end{array}$ \\
\hline $\begin{array}{l}6 \text { Environmental impact } \\
\text { of production }\end{array}$ & $\begin{array}{l}\text { moderate but } \\
\text { harmful }\end{array}$ & $\begin{array}{l}\text { very big and } \\
\text { harmful }\end{array}$ & still harmful \\
\hline 7. Literacy & insignificant & high & total \\
\hline $\begin{array}{l}8 . \quad \text { Average school } \\
\text { attendance (in years) }\end{array}$ & $2-4$ & $10-12$ & $16-20$ \\
\hline $\begin{array}{l}\text { 9. Higher education as a } \\
\text { phenomenon }\end{array}$ & unique & widespread & almost obliged \\
\hline $\begin{array}{l}10 \text { Mobility in higher } \\
\text { education }\end{array}$ & very low & insignificant & high \\
\hline $\begin{array}{l}\text { 11. Higher education } \\
\text { (years) }\end{array}$ & $3-4$ & $3-7$ & $4-9$ \\
\hline 12. Number of degrees & 1 & $1-3$ & $3-5$ \\
\hline $\begin{array}{l}\text { 13. The nature of the } \\
\text { diplomas }\end{array}$ & local & national & national / international \\
\hline
\end{tabular}

It follows from the table that higher education emerged to meet the needs of very large associations of people and is the result of the emergence of relatively developed societies with great need not only of ordinary executives but also of the highest level of competence workers in critically important sectors of activity, from management and religion to defense, and scientific research. We believe that the modern model of the highert education, as part of society and economy, was created in the Byzantine Empire. Its effectiveness explains the long-term political, social and economic success of the empire in a very hostile environment.

In the future, these achievements have been continuously improved in Europe, where the hottest competition involving many rivals with roughly the same capabilities was launched. If Great Britain was the leader among political and social innovators, the Germans in the period of liquidation of fragmentation created the most 
perfect high school, almost perfectly adapted to the needs of the industrial society. The model of the Berlin Research University has become a model for copying around the world. Yet higher education was a unique phenomenon, so in 1900 there were two universities with a contingent of more than 10 thousand students Berlin and the Sorbonne. It should be noted that at that time, the University of Kyiv was among the 25 largest universities.

For the topic of this article, it is important to emphasize that for almost a century Germany has become the center of attraction for the youth of developed countries and formed rules for the reception of foreigners and the basis for the provision of educational services of the modern type. It was a significant step towards the internationalization of higher education through the interaction of national institutions, since earlier mobility was based only on the teaching of the Latin for the universal high school in Europe.

Let's turn to the semantic background of our study and consider the modern notion of the terms "globalization"

"internationalization of higher education".

By the efforts of the media, political scientists and specialists in social and economic sciences, at the turn of the century, a general conviction was formed that at present globalization has become not only a powerful, but also the most common feature of a constantly changing world environment with a multitude of qualitative and quantitative features.
Their more or less complete list with short explanations filled more than a thousand pages in the Encyclopedia of "Globalistics" [1], among 647 authors there can be found scholars from Ukraine (in particular, Dr. B. Lyakh and I. Predborska) .

From available sources, we found that an absolute majority of researchers of globalist phenomena belong to humanities. Therefore, the mega-encyclopedia does not even mention the influence of modern science and technology, and the role of the whole scientific and educational complex has not been investigated. Obviously, this feature has reduced the value of "Globalistics" as a source of forecasts for the future. This deformation of attention forms the false idea of the importance of information tools - PCs, gadgets, and others. We have not found examples of the fact that even one great powerful state in the last half century built all its success in the global world on ICTs and gadgets. Germany, Japan, China, USA, or Brazil did this because of the improvement of material production of the 5th and 6th levels.

In the West, there is epidemic use of the English word "Smart", which will soon absorb Ukraine. We regret that this will happen, because the "smart society" seems to be such that even children will not miss out "smart gadgets" for almost whole day. Unfortunately, little is written about obtaining in this way many kinds of entertainment, excessive and unnatural (sometimes, frankly dangerous) contacts, and most importantly about the enormous 
difficulty for the formation of critical thinking in the students, and absolutely necessary for safe living, for creativity of the foundations of scientific knowledge

Usually researchers in text and ematerials consider globalization, positioning it as a key factor in an environment that has a different impact on education, both positive and negative.

This is especially evident in the works of experts on comparative pedagogy and sociology of education. For example, F. Altbach considers globalization as "key reality in the 21st century, has already profoundly influenced higher education. We define globalization as the reality shaped by an increasingly integrated world economy, new information and communications technology (ICT), the emergence of an international knowledge network, the role of the English language, and other forces beyond the control of academic institutions" [4, p. iv].

J. Knight has an even broader vision, defining globalization as "the flow of technology, economy, knowledge, people, values and ideas .... across borders. Globalization affects each country in a different way due to each nation's individual history, traditions, cultures, resources and priorities" [7, p. 6].

Quite logically and justified internationalization and globalization are seen as different but dynamically interconnected phenomena. These definitions will be considered as working, neutral from the international point of view and which do not include measures, justifications and results, leveling off their shortcomings or one-sidedness. This approach even became an impetus for a kind of worldview: internationalization began to understand the process as opposed to the concept of "international education" focused on the final product.

However, as evidenced by the evolution of knowledge and technology, not always after the terminological changes real changes happened in practice. Sometimes such a delay went even for the benefit of higher school, because it saved from the introduction of false theories. So on this topic, increased attention to the international dimension in higher education is particularly visible not in legislative reforms, but in international, national discussions and reflections that are formed at the institutional level.

Foreign sources give us information on the increasing global competition for the attraction of talented students, academics and teachers, the emergence of foreign affiliates of university campuses, the complication of cross-border activities, the controversy around the remuneration of agents for the search and involvement of foreign students, etc. Previously, this was not the case, and today they are at the center of the agenda not only for the international community of education workers, but also for presidents and university associations, politicians and responsible state administrators.

We especially consider the emergence of auxiliary adjectives ("comprehensive", "deep", etc.), the 
beginning of the formation of a system of international measurement in the global knowledge economy, the increasing influence of market factors, and we consider this trend far from the full usefulness - the inclusion of educational services in the list globally important and promising. Let's emphasize: it is a question of "services", and not the preparation of youth to the level of a competent citizen of the future society.

We consider it useful to have a certain differentiation of fundamental concepts. J. Knight distinguishes two types of internationalization of higher education: internationalization at home - a trend that helps students develop international understanding and intercultural skills while studying in their country, and internationalization abroad (often narrowing down to the concept of cross-border education).

Internal internationalization is the inclusion of international curriculum subjects and programs, teaching and learning processes, non-auditing activities, interactions with local cultural / ethnic groups, as well as research and research. It aims to prepare students who are not able to study abroad, to live and work in a globalized world.

Internationalization abroad, including all forms of cross-border education, is the mobility of students and teachers, the mobility of projects, programs and service providers. These types can not be regarded as mutually exclusive, they are intertwined in policies and programs [9, p. 22-24].

$\mathrm{U}$. Teichler rightly notes the trend of changing the meaning of important concepts: "Globalisation initially seemed to be defined as the totality of substantial

changes in the context and inner life of higher education related to growing interrelationships between different parts of the world whereby national borders are blurred or even seem to vanish. In recent years the term "globalisation" is substituted for "internationalisation" in the public debate on higher education, whereby a shift of meaning takes place. No interest is paid anymore to whether the phenomena are linked to a blurring or vanishing of borders. Rather, the term tends to

be used for any supra-regional phenomenon related to higher education (anything which seems to take world-wide) and/or anything on a global scale related to higher education characterised by market and competition" [12, p. 23].

Consequently, a consensus has emerged on the deep interconnectivity of globalization and internationalization. J. Knight defines "a) the knowledge society, (b) information and communication technologies, (c) the market economy, (d) trade liberalization, and (e) changes in governance structures" [9, p. 5]. From this it follows that globalization causes not only one internationalization, first of all education without borders. Borders are of great importance when it comes to responsibility for the quality of education, access to it and funding. Most notably, it is within the framework of various regional associations of states created to achieve economic integration, social 
cohesion and political security. The most successful of them are the EU and Council of Europe programs, the creation of the European Higher Education Area (EHEA) within the Bologna Process and the European Research Area (ERA) within the framework of the Lisbon Strategy.

Let's restrict ourselves to the reminder that the Bologna Process and the Lisbon Strategy are an example of the regionalization of international cooperation in Europe. The purpose of the Bologna Process is to make European higher education more attractive and more competitive from the standpoint of its international dimension. It has become an example for the creation of various associations in other parts of the world that support international cooperation in higher education. The volume of the article does not allow data on higher education internationalization initiatives in the Latin American and Caribbean regions (Espacio de Encuentro Latinoamericano y Caribeño de Educación Superior, ENLACES); African Network for Internationalization of Education (ANIE); Asia-Pacific Brisbane Communiqué. Intensified educational cooperation in South-East Asia, within the Asia-Pacific Economic Cooperation (APEC) and North American Free Trade Association (NAFTA). All this suggests that the process of internationalization of higher education has become a truly global phenomenon.

Everyone agrees that the international and intercultural aspects of educational programs and the teaching, learning, and research (c) Debych M. A., Humenna O. A., 2018 processes in case of their proper use are important for improving the quality of national higher education. It should be noted that the goals of internationalization and expected benefits differ both in countries and in the higher educational establishments, but in general, everyone hopes that internationalization will contribute to improving the quality and relevance of higher education in an interconnected and interdependent world, the development of intercultural and transcultural competencies in graduates, will promote employment in the international labor market and mutual understanding among peoples. Ensuring the quality of education, promoting equal access to it, empowerment of students at the time they make decisions on their individual life paths relate to the most important challenges facing higher education in a context of growing globalization.

World higher education enters a new state when it gradually becomes massive and should work for a postindustrial economy and a knowledge society. Already, the OECD has provided evidence that demand for university education is increasing geometrically and instead of the current 99 million students will provide approximately 414 million in 2030 [6]. In addition, in the sector of higher education, the number of international students in the vast majority of countries of the world is increasing. As of 2017, there are 4.6 million international students in the world [8], and in 15 years they can become ten times more (but only in 
the event of the elimination of the negative effects of global immigration from poor countries to the rich).

All these processes are of great interest to the World Trade Organization. As a result, the General Agreement on Trade in Services (GATS) came into force. In this agreement, education is considered as a service and establishes specific rules and conditions for the liberalization and regulation of trade in similar services. "The inclusion of trade in higher education services within the framework of GATS is a reality and will not change. Each country can determine the extent to which it will permit foreign education service providers to access the domestic market."[7, p. 9].

S. Marginson and M. van der Wendt point out that "inclusion is seen as a driver of change and national benefit by governments that have an interest in educational trade or see the GATS agenda as potentially helpful in implementing reforms along new public management lines. Critical responses to WTO/GATS range from concerns about vulnerable systems in developing nations, to the effects of foreign competition in established systems, to opposition to globalisation as such. [11, p. 8].

Consequently, some countries oppose higher education as a commodity. Others consider the commercialization and trade in services in higher education to be the driving force behind the reform of higher education. It should be noted that a market approach to higher education is being supported by the developing countries as well as countries with economies in transition. These countries are not only markets for higher education services but also active participants in the international educational services market. In particular, the number of foreign students in China has grown and already accounts for $10 \%$ of the number of international students in the world [8]. Recently, Japan, where demographic problems have a minus sign, for the first time invites guest workers and future students.

Trade in educational services exists, and thanks to it there are new opportunities for higher educational establishments and challenges arise. In particular, "increased supply of education and greater access for students, support for the knowledge economy, development of joint degrees, fusion or hybridization of cultures, growing comparability of qualifi cations, increasing role for market-based approach, economic benefi ts for education providers, and diversification and generation of new academic environments. The potential challenges are also numerous and varied. They include concern about quality of provision, inequality of access leading to a two-tier system, the growing problem of physical and virtual brain drain on the developed country-developing country axis but also on other routes, homogenization of culture, weakening role of the state in establishing national policy objectives, growth in market-oriented programmes such as business and information technology and decline in some liberal arts and pure science disciplines" [7, p. 14]. 
In this paragraph, the notion of "joint / double degrees" is mentioned. We consider it necessary to emphasize this phenomenon and pay special attention to it.

It's time for us to go over to generalizations and conclusions. To do this, once again take a look at the data presented in Table 1. Obviously, the economic and social progress of humanity was based on technical and technological inventions, improvement of energy sources, tools and machines. In agrarian time there was trade and exchanges, but practically all products were national in the sense that they did not contain components manufactured in other states. Even the output of industrial production at the level of mass circulation did little to change: the famous black car G. Ford was entirely American and was treated as a national engine.

But after the Second World War, the division of labor deepened so that more and more products of the 4th and 5th levels in country " $\mathrm{A}$ " became a combination of smaller parts or fragments. For the common economic benefit, the process of fragmentation of the composition of primary producers has occurred, and for example, modern computers or other products include the results of labor workers from many countries. We propose to name this already well- developed world phenomenon "internationalization of production".

Conclusion. Our idea, central to this article, is that such a division of curricula, institutions, internships, etc. is rapidly deepening in the process of training a modern intellectual worker who holds a PhD-diploma or equivalent. Instead of providing the necessary competencies within a single state, Singapore or China, it is more profitable to find basic schooling in one place, a profile secondary in another, a baccalaureate or master's program in the country "A", postgraduate study somewhere in "B", the final professional improvement at the best in the world center of MBA or some other training in Oxford or Harvard.

From this follows the following conclusion: Ukraine's resources, or even a larger state, are already inadequate for the preparation of national world-class personnel. Such a "product" has already became international.

That is why we are convinced that, with the development of the 21st century, higher education of the elite quality can not be provided by national "world-class universities" (which are also actively explored in Ukraine [10]). Youth with the highest competence is the product of this international higher education, a new world-class formation that is developing rapidly on the planet.

\section{References}

1. Mazur, I. I., Chumakov, A. N. (Eds.) (2006). Globalization: International Interdisciplinary Encyclopedic Dictionary . Moscow-Sankt-Peterburg.

2. Bell, D. (1999). The future post-industrial society. Experiences of social forecasting. Translation from English. Moscow: Academia. 
3. Toffler, E. (2000). Third wave. Kyiv: Universe.

4. Altbach, P., Reisberg, L., Rumbley, L. (2009). Trends in Global Higher Education: Tracking an Academic Revolution. Paris, UNESCO, 278. Available at: http://www.cep.edu.rs/public/Altbach,_Reisberg,_Rumbley_Tracking_an_Academic_Revolut ion, UNESCO_2009.pdf

5. Bell, D. (1976). The Cultural Contradictions of Capitalism. New York: Basic Books, 301.

6. Education at a Glance 2012 (2012). OECD Indicators. Paris: OECD Publishing. doi: https://doi.org/10.1787/eag-2012-en

7. Higher Education in a Globalized Society (2004). UNESCO Education Position Paper. UNESCO, Printed in France (ED-2004/WS/33). Available at: http://unesdoc.unesco.org/images/0013/001362/136247e.pdf

8. Project Atlas 2018: Infographics. Available at: https://www.iie.org/Research-andInsights/Project-Atlas/Explore-Data/Current-Infographics

9. Knight, J. (2008). Higher Education in Turmoil: The Changing World of Internationalization. Rotterdam, Netherlands: Sense Publishers. Available at: https://www.sensepublishers.com/media/475-higher-education-in-turmoil.pdf

10. Kurbatov, S. (2018). University Rankings and the Problem of Quality Assurance of Teaching and Learning Processes. Higher Education of Ukraine, 4 (71), 25-29.

11. Marginson, S., van der Wende (2015). Globalisation and Higher Education. OECD Education Working Papers, No. 8, OECD Publishing.

12. Teichler, U. (2004). The changing debate on internationalisaton of higher education. Higher education, 48, 5-26. Available at: http://diversity.cofc.edu/journalarticles/internationalisation-of-higher-education

13. Ripple, W. J., Wolf, C., Newsome, T. M., Galetti, M., Alamgir, M. et. al. (2017). World Scientists' Warning to Humanity: A Second Notice. BioScience, 67 (12), 1026-1028. doi: https://doi.org/10.1093/biosci/bix125

ДЕБИЧ, М. А., - кандидат педагогічних наук, доцент, старший науковий співробітник, Інститут вищої освіти Національної академії педагогічних наук (Київ, Україна)

E-mail: m_debych@ukr.net, ORCID: 0000-0002-5999-3989

ГУМЕННА, О. А., - аспірантка відділу політики та врядування у вищій освіті, Інститут вищої освіти Національної академії педагогічних наук (Київ, Україна)

E-mail: enrietta@ukr.net, ORCID: 0000-0003-3644-8758

\section{ЕЛІТАРНА ЯКІСТЬ ВИЩОЇ ОСВІТИ ЯК НАСЛІДОК ГЛОБАЛЬНОЇ ІНТЕРНАЦІОНАЛІЗАЦІї}

Актуальність і розробка проблеми. Після II світової війни керівники і провідні науковці людства були змушені шукати нові принципи і методи управління. 3'явилися нові теорії аналізу складних систем. Група Д. Медоуза в Римському клубі та інші аналітики виявили факт занурення людства в незворотну i смертельну кризу. Досьогодні економісти і політики не запропонували спосіб гарантувати порятунок. Однак $є$ консенсус, що надії можуть бути пов'язані з розвитком освіти та науки в світі. Тому все частіше використовується фраза «інтернаціоналізація вищої освіти (IBO)», а кількість наукових праць стрімко зростає. Однак, на нашу думку, феномен IBO сприймається поверхово через неуважність до останніх наукових досягнень, за якими не слідкують науковці-гуманітарії. Це викликало наш інтерес і стимулювало прагнення

The elite quality of higher education as a consequence of global internationalization 
довести, що в світі процес IBO розпочався відповідно до законів еволюції промислового виробництва.

Метою нашого дослідження $є$ застосування теорії аналізу дуже великих систем до явищ інтернаціоналізації всіх видів і варіантів для отримання найбільш ймовірних сценаріїв людського прогресу. Завдання дослідження ми вбачаємо в критичному аналізі поміченого нами тренду фрагментації процесу підготовки кадрів найвищих кваліфікацій у просторі й часі та перетворення фігури молодого працівника 3 національного в інтернаціональний “продукт” діяльності наявних класичних і нових систем навчання і професійної підготовки.

Результати дослідження в своїй основі все ж спираються на історичні методи у поєднанні з досягненннями молодих наук - синергетики, теорій складних систпем та ін. Була створена оригінальна таблиця задля співставлення аграрного, індустрального та інформаційного суспільств - тих, у межах яких зростала система вищої освіти. Наведення іï характеристк довело, що з наближенням до сьогодення зменшувалася автономія університетів, зростав розмір всієї системи та ії орієнтованість на політичноекономічні запити. Вказано період часу, коли вища школа розпочала втрачати свій національний характер і набувати рис інтернаціональності. Відзначено, що це співпало зі зростанням обсягу і впливу глобалізації та вивченням іiі переважно у межах гуманітарних наук.

У статті викладено поширені уявлення про взаємодію у вищій освіті впливів глобалізації та інтернаціоналізації, основні визначення і диференціацію тощо. Наведені новітні дані про врахування інтернаціоналізації у межах університетів та далеко поза ними в державних та міждержавних інституціях. У висновках i рекомендаціях сформульована i доведена основна гіпотеза всього нашого дослідження та його головний результат. Він полягає у тому, що вища школа в цілому стала відтворювати шлях промисловості 3 iї варіантом інтернаціоналізації - поєднанням у виробах продукції багатьох держав.

Наш висновок: ми стверджуємо, що і у вищій освіті розпочався поділ у часі й просторі навчальних програм, закладів, місць стажування і т.д. Замість забезпечення отримання $\mathrm{PhD}$-компетентності у межах однієї держави вигіднішим виявляється базове шкільне навчання в одному місці, профільне середнє - в іншому, бакалаврська чи магістерська програма у країні “А”, аспірантура - десь у “В”, остаточне професійне вдосконалення - у кращому в світі центрі з МВА чи якоїсь іншої підготовки в Лондоні чи Гарварді. 3 цього випливає що ресурси України чи навіть більшої держави вже виявляються недостатніми для підготовки національних кадрів найвищої можливої світової якості. Подібний “продукт” вже став інтернаціональним.

Ключові слова: еволюція вищої освіти, криза людства, роль наук і вищої освіти, глобалізація та інтернаціоналізація, якість вищої освіти, $\mathrm{PhD}$-фахівці як інтернаціональний “продукт”.

ДЕБИЧ, М. А. - кандидат педагогических наук, доцент, старший научный сотрудник, Институт высшего образования Национальной академии педагогических наук (Киев, Украина)

E-mail: m_debych@ukr.net, ORCID: 0000-0002-5999-3989

ГУМЕННА, Е. А. - аспирантка отдела политики и управления в высшем образовании, Институт высшего образования Национальной академии педагогических наук (Киев, Украина)

E-mail: enrietta@ukr.net, ORCID: 0000-0003-3644-8758 


\section{ЭЛИТАРНОЕ КАЧЕСТВО ВЫСШЕГО ОБРАЗОВАНИЯ КАК СЛЕДСТВИЕ ГЛОБАЛЬНОЙ ИНТЕРНАЦИОНАЛИЗАЦИИ}

Актуальность и разработка проблемы. После II мировой войны руководители и ведущие ученые человечества были вынуждены искать новые принципы и методы управления. Появились новые теории анализа сложных систем. Группа Д. Медоуза в Римском клубе и другие аналитики обнаружили факт погружения человечества в необратимый и смертельный кризис. До сих пор экономисты и политики не предложили способ гарантировать спасение. Однако есть консенсус, что надежды могут быть связаны с развитием образования и науки в мире. Поэтому все чаще используется фраза «интернационализация высшего образования (ИВО)», Однако, в подобных материалах, по нашему мнению, явление интернационализации высшего образования осознается поверхностно, что обусловлено преимущественно невниманием к новейшим научным достижениям, за которыми не следят исследователи-гуманитарии. Это вызвало наш интерес и стимулировало желание доказать, что в мире начался процесс тотально глобальной интернационализации высшей школы согласно законам эволюции не образования, а промышленных производств.

Цель нашего исследования - применение теории анализа очень больших систем к явлениям интернационализации всех видов и вариантов с получением максимально достоверных сценариев прогресса человечества.

Задачи исследования мы видим в критическом анализе замеченного нами тренда фрагментации процесса подготовки кадров высших квалификаций в пространстве и времени и преобразования фигуры молодого работника из национального в международный «продукт» деятельности имеющихся классических и новых систем обучения и профессиональной подготовки.

Методологию исследования диктовали цель и задачи под давлением грандиозности объема и сложности объекта исследования - комплекса систем образования в глобальной всепланетной среде. Этим обусловлено использование средств многих наук, теорий системных исследований и мультидисциплинарный подход в условиях глобального эволюционизма.

Результаты исследования в своей основе все же опираются на исторические методы в сочетании с достижениями молодых наук - синергетики, теории сложных систем и др. Была создана оригинальная таблица для сопоставления аграрного, индустрального и информационного обществ - тех, в пределах которых развивалась система высшего образования. Наведение ее характеристик доказало, что с приближением к настоящему уменьшалась автономия университетов, рос размер всей системы и ее ориентированность на политико-экономические запросы. Указан тот период времени, когда высшая школа начала терять свой национальный характер и приобретать черты интернациональности. Отмечено, что это совпало с ростом объема и влияния глобализации и изучением ее преимущественно в пределах гуманитарных наук. Изложены распространенные представления о взаимодействии в высшем образовании воздействий глобализации и интернационализации, основные определения и дифференциации и тому подобное. Приведены новейшие данные об учете интернационализации в пределах университетов и далеко за их пределами в государственных и межгосударственных институциях. В выводах и рекомендациях сформулирована и доказана основная гипотеза всего нашего исследования и его главный результат. Он состоит в том, что высшая школа в целом стала воспроизводить путь промышленности с ее вариантом интернационализации - сочетанием в изделиях продукции многих государств.

The elite quality of higher education as a consequence of global internationalization 
Главный вывод: мы утверждаем, что и в высшем образовании началось разделение во времени и пространстве учебных программ, заведений, мест стажировок и т.д. Вместо обеспечения получения $\mathrm{PhD}$-компетентности в пределах одного государства выгоднее оказывается базовое школьное образование в одном месте, профильное среднее в другом, бакалаврская или магистерская программа в стране «А», аспирантура где-то в «В», окончательное профессиональное совершенствование в лучшем в мире центре МВА или какой-то другой подготовки в Лондоне или Гарварде. Из этого следует вывод: ресурсы Украины или другого государства уже оказываются недостаточными для подготовки национальных кадров наивысшего мирового качества. Подобный «продукт» уже стал интернациональным.

Стаття рекомендована до публікації д.філософ.н., проф. І. С.Рижовою (Запоріжжя, Україна)

Надійшла до редколегії: 11.12.2018 p. Прийнята до друку: 16.12.2018 p. 